fiscally and ideologically attractive advice. Supporters of the findings hope that laboratory directors - who dislike existing DoE oversight arrangements, and have good congressional connections -- will help win support for radical reforms.

But Nick Samios, director of the Brookhaven National Laboratory, New York, says that reform could work within the existing, government-owned, contractor-operated (GoCo) system. "I know that a real GoCo will work," he says, claiming that 'corporatization' could damage the laboratories. "I'm not against it," he says. "I just want to see what it is."

Bruce Tarter, director of the Lawrence Livermore National Laboratory in California, which Galvin said should lose its nuclear weapons design capability, issued a statement predicting that Galvin's recommendations "will turn out differently" when evaluated in the context of the entire nuclear weapons programme.

Others suggest even more radical steps. An "Alternative Galvin Report", published by the Military Production Network (MPN), an environmentalist coalition, urged Congress to save $\$ 4$ billion over four years by simply scrapping nuclear weapons research altogether.

"Continued weapons research, development and testing is contrary to stated national goals of 'reducing the global nuclear danger," MPN says. "It's time to end the Manhattan Project."

Colin Macilwain

\section{Gene therapy trial passed in Japan}

Tokyo. Japan's first clinical application of gene therapy was approved earlier this week by a committee of the Ministry of Health and Welfare (MHW).

A research team led by Yukio Sakiyama of Hokkaido University School of Medicine was given permission by the ministry's central assessment committee for gene therapy to carry out clinical research in gene therapy in order to treat a four-year-old boy suffering from adenosine deaminase (ADA) deficiency, an enzyme deficiency that weakens the immune system.

The permission has been given on condition that Sakiyama makes some revisions to the forms used to obtain informed consent from the patient, and that he explains the treatment once more to the boy's parents.

The treatment he plans to use is based on a technique developed five years ago at the US National Institutes of Health (NIH). It involves introducing the ADA gene to the child's T-lymphocytes using a bacterial gene for neomycin resistance.

Sakiyama had initially proposed a slight modification of the technique. But during the approval process this idea was dropped for safety reasons, and he will now use an identical technique to that
London. The British government announced last week that it is to increase funding for 'strategic' science initiatives and for collaboration with industry by $£ 67$ million in the financial year starting on 1 April, equivalent to around five per cent of the total budget of $£ 1,281.7$ million.

Overall, however, the science budget will increase by 3.3 per cent next year, slightly higher than the anticipated rate of inflation. The emphasis being given to strategic initiatives will inevitably mean less money for areas of basic science, and is already causing difficulties in areas such as astronomy (see page 459).

In announcing the allocation of the science budget for 1995-96, David Hunt, minister for science, said that the support for strategic initiatives is intended to promote policies highlighted in the government's science and technology white paper of May 1993, Realising Our Potential.

The money will be used to extend existing schemes to improve interaction with industry - such as the Realising Our Potential Awards (ROPA) scheme - to increase funding for 'underpinning' strategic science in physics, mathematics, medicine and biol-

already successfully used by Michael Blaese of NIH.

Because the retroviral vector to be used in the treatment is not available in Japan, Sakiyama has to obtain approval from the US Food and Drug Administration for the export of the vector by $\mathrm{Ge}$ netic Therapeutic Inc. of Maryland. As a result, he is not expected to be able to begin treatment until about April.

The approval this week was the last step in a complex process overseen by the MHW committee and another separate committee in the Ministry of Education, Science and Culture. That committee, which was concerned with scientific and safety issues, gave its approval last week.

The MHW committee meeting, which unusually for Japan was open to the press, concentrated on the issue of informed consent, for which Sakiyama is using detailed forms based on a translation of those being used by Blaese in the United States.

There is still little awareness among Japan's medical profession of the Western concept of informed consent, and one additional benefit of the application of gene therapy may be a more rigorous approach to this issue in general medical practice. David Swinbanks

\title{
UK shifts research support into 'strategic' initiatives
}

ogy, and to enhance 'people-related programmes', including the promotion of the public understanding of science.

Sir John Cadogan, director general of the research councils, has 'ring-fenced' £8 million of the science budget to insulate the Particle Physics and Astronomy Research Council (PPARC) from fluctuations in its international subscriptions due to changes in exchange rates. PPARC had complained that increases in subscriptions to the European Laboratory for Particle Physics (CERN) and the European Space Agency had left it unable to fund instrumentation and scientists to exploit the contributions. Cadogan said the chief executives of the other councils agreed to the ring-fencing, but were watching the money "like hawks".

The ROPA scheme, which funds researchers who are already working in collaboration with industry, will be one of the main beneficiaries of the new budget, with additional funding of $£ 14.95$ million that will allow it to extend to all six research councils. Cadogan says the outcome will be "blue-skies curiosity-driven research" that will also benefit strategic research.

Another winner in the budget will be the LINK scheme, soon to be relaunched with $£ 3$ million earmarked from the research councils' budgets. The Medical Research Council (MRC)'s genome research programme gets a $£ 3.5$-million fillip.

Chemistry is to retain enhanced support through the Biotechnology and Biological Sciences Research Council (BBSRC), the Engineering and Physical Sciences Research Council (EPSRC) and the Natural Environmental Research Council (NERC), at a total of $£ 7.6$ million.

Physics, mathematics and medicine benefit from $£ 4.4$ million allocated for strategic initiatives, and the BBSRC will receive an extra $£ 2$ million to support research that underpins emerging technologies in bioprocessing and developing 'wealth-creating products' from plants, such as vaccines and biopharmaceuticals.

The Royal Society will also benefit from an increase in the number of its research fellowships from 200 to 255 . Extra funding will also allow it to introduce new fellowships to promote the role of women in science, named after the late Dorothy Hodgkin.

The lack of overall growth in funding has already brought criticism from groups such as the Institute of Professional, Managers and Specialists, the labour union which represents many research council staff. But Hunt described the budget package as "a vote of confidence in the country's engineers, mathematicians, natural and social scientists".

Maggie Verrall 